\title{
ASSESSMENT OF CHANGES IN SOD UNDER INTENSIVE USE
}

\author{
Jarosław Czarnecki $^{1 *}$, Anna Cudzik ${ }^{1}$, Marek Brennensthul ${ }^{1}$, Włodzimierz Białczyk ${ }^{1}$, \\ Karol Wolski ${ }^{2}$, Sebastian Świerszcz ${ }^{2}$ \\ ${ }^{1}$ Department of Agricultural Engineering, Wrocław University of Environmental and Life Sciences \\ ${ }^{2}$ Department of Food Storage and Technology, Wrocław University of Environmental and Life \\ Sciences \\ "Corresponding author: e-mail: jaroslaw.czarnecki@up.wroc.pl
}

\begin{tabular}{|c|c|}
\hline ARTICLE INFO & ABSTRACT \\
\hline $\begin{array}{l}\text { Article history: } \\
\text { Received: April } 2017 \\
\text { Received in the revised form: } \\
\text { May } 2017 \\
\text { Accepted: May } 2017 \\
\end{array}$ & \multirow{2}{*}{$\begin{array}{l}\text { The paper presents research results which aimed at evaluation of the } \\
\text { change in the sodding degree and selected strength parameters of sod } \\
\text { used with varied intensity; additionally sod was modified through } \\
\text { administration of biopreparation. Measurements were taken on two } \\
\text { types of sod. The first one was formed from perennial rye grass, the } \\
\text { second one from orchard grass. It was proved that the use of the } \\
\text { investigated facilities resulted in reduction of sodding, which was } \\
\text { related to the sod forming species. No impact of biopreparation use on } \\
\text { the sodding degree was proved. Intensive use affected the increase of } \\
\text { the value of the analysed strength parameters; at low soil moisture } \\
\text { (5.0-5.5\%) considerable compaction in the surface layer of soil was } \\
\text { reported. }\end{array}$} \\
\hline $\begin{array}{l}\text { Key words: } \\
\text { sod, } \\
\text { compactness, } \\
\text { maximum shear stress, } \\
\text { sodding }\end{array}$ & \\
\hline
\end{tabular}

\section{Introduction}

Intensive use of agricultural surfaces causes changes in soil environment and in growing plants (Serensits et al., 2011; Błażejczak et al., 2008). Soil gets compacted, as a result of which unfavourable changes, such as reduction of water and air conductivity and water retention, in its properties take place (Janik et al., 2015). Shape and distribution of soil pores changes, which impedes availability and transport of air and causes accumulation of carbon dioxide (Turgeon, 2005). In the compacted sodded ground, the plant root system changes with regard to quality and quantity, distribution of grass roots changes and causes dysfunctions (Follis, 2008). Soil compaction in the surface layer is particularly dangerous since there a mechanical resistance impedes correct development of the plant root system (Cook et al., 1996).

The use also influences changes in aboveground plant parts. Mechanical damage of plants results in increased susceptibility to pests and pathogens, and precious species are replaced by weeds (Grime et al., 1992). Plant growth inhibition is a total effect of intensive use; sod density decreases and preterm ageing of plants takes place (McNitt et al., 2004; Głąb, 1999). Sensitive plants are reduced in sod, which means that its botanical composition and species diversity changes (Danneberger, 1993). However, results of current research are not explicit. Except for the above indicated changes in sod, also cases of positive 
reactions related to stimulating influence of compaction to growth and development of plants are described. Kopeć and Głąb (2002) indicated that the treatment of packing improves root development of $L$. perenne $\mathrm{L}$. which is related to the morphological structure of grasses (McNitt et al., 2004). Research on the impact of dead organic matter on sod were carried out. A small amount of felt is desired. It increases sod elasticity, functions as a buffer against border temperatures, limits weeds and increases resistance of grasses to intensive use (McCarty et al., 2005). The size of sodding and occurring mat improve elasticity of ground, limit effect of pressing force (Samaranayake et al., 2008).

\section{Objective of the paper, methodology and conditions of the research}

The objective of the research was to evaluate the sodding degree and selected strength parameters of sod with varied species composition of plants. The research was carried out in conditions of varied intensity of sod use and additionally, experiment was modified by the use of biopreparation.

The research was carried out in facilities of the Agricultural Experimental Institute Swojec belonging to Wroclaw University of Life Sciences in Spring 2015 on three measurement dates. The field experiment was set on fen soil made of loam with 'split-splot' method in three iterations. Research was carried out on two basic types of mature - 2-year old sod, where in facility I perennial rye - grass Lolium perenne L. Temprano cultivar was sown; rate of seeding was $31 \mathrm{~kg} \cdot \mathrm{ha}^{-1}$. Orchard grass Dactylis glomerata L. Atios cultivar was sown in facility II, rate of seeding was $21 \mathrm{~kg} \cdot \mathrm{ha}^{-1}$. Energen Fulhum was applied in the dose of $0.25 \mathrm{l} \cdot \mathrm{ha}^{-1}$ in the experiment.

The soil compaction was measured with Eijkelkamp penetrologger with a cone penetrometer with a vertical angle of $60^{\circ}$ and the surface area of the base of $0.0001 \mathrm{~m}^{2}$, at the movement speed of $0.03 \mathrm{~m} \cdot \mathrm{s}^{-1}$. Moreover, soil moisture was determined with Theta Probe ML 2x probe which constitutes additional equipment for the penetrologger. The value of the measured moisture of sod soil was placed in table 1.

Table 1.

Sod soil moisture in investigated facilities

\begin{tabular}{lccccc}
\hline & & \multicolumn{4}{c}{$\begin{array}{c}\text { Moisture } \\
(\%)\end{array}$} \\
\cline { 3 - 6 } $\begin{array}{l}\text { Usage level } \\
\text { M) }\end{array}$ & Measurement & \multicolumn{3}{c}{$\begin{array}{c}\text { With } \\
\text { date }\end{array}$} & \multicolumn{2}{c}{$\begin{array}{c}\text { Without } \\
\text { biopreparation }\end{array}$} & \multicolumn{2}{c}{ biopreparation } \\
\cline { 3 - 6 } & & 5.0 & 5.1 & 5.3 & 5.2 \\
\cline { 3 - 6 } & & Facility I & Facility II & Facility I & Facility II \\
\hline 0 & I & 5.5 & 5.4 & 5.4 & 5.5 \\
100 & & 5.2 & 5.4 & 5.1 & 5.3 \\
\hline 0 & \multirow{2}{*}{ II } & 12.3 & 12.4 & 13.2 & 13.6 \\
50 & & 13.8 & 13.9 & 14.2 & 13.9 \\
100 & & 15.5 & 15.6 & 16.1 & 15.9 \\
\hline 0 & III & 14.8 & 14.9 & 15.2 & 15.4 \\
50 & & 15.8 & 16.2 & 15.4 & 16.3 \\
100 & & 17.1 & 16.8 & 17.3 & 17.2 \\
\hline
\end{tabular}


Assessment of changes...

The maximum shear stresses were carried out with a shear vane Vaen H-60 by Geonor company. A measuring probe of the vane was placed in sod then a rotation was made to the moment the surface was cut off, the value of stresses was read from the scale with the measurement scope from 0 to $260 \mathrm{kPa}$. Measurements of compaction and maximum shearing stresses were carried out in the layer of 0-0.15 m.

The change of the usage intensity (compaction) of sod was obtained by a varied number of trips of a roller, on the circumference of which, conic wing dams of $0.014 \mathrm{~m}$ diameter and $0.02 \mathrm{~m}$ height were screwed in. This roller, which was loaded respectively, ensured unit pressures at the level of $30 \mathrm{kPa}$. By a respective number of trips with a roller, three levels of sod usage were obtained. Level $0 \%$ meant non-compacted sod, fifty trips with a roller meant $50 \%$ usage level and 100 trips meant $100 \%$ of the usage level (Białczyk et al., 2010). The sod formation level was measured with Weber squares method. The obtained results were subjected to the statistical analysis; a two-way ANOVA at the level of $\alpha=0.05$ and HSD Tukey test were carried out.

\section{Analysis of results}

Measurement of sodding before the facility was used on the first measurement date proves the highest values of this parameter. For facilities, where no biopreparation was applied, sod formation was within $82-84 \%$. For facilities with the applied biopreparation, higher values of this parameter within 91-94\% were reported. Table 2 presents sodding values of the investigated facilities and on the 2nd and 3rd measurement date for the assumed usage levels. Changes of this parameter between the investigated facilities were proved. Generally, facility II had higher values of sodding and the increase of the usage degree resulted in the reduction of sodding. Higher values of this parameter on the 3rd measurement date prove regeneration of sod and gradual return to the state before use. Administration of biopreparations may reduce grasses susceptibility to damage, increase density of green plants and root system (Serensits, 2011). However, in this research, the use of biosubstance did not cause the increase of sodding.

Table 2.

Sod formation of the investigated facilities

\begin{tabular}{lccccc}
\hline & & \multicolumn{4}{c}{$\begin{array}{c}\text { Sod formation } \\
(\%)\end{array}$} \\
\cline { 3 - 6 } $\begin{array}{l}\text { Usage level } \\
\text { Level of usage }\end{array}$ & $\begin{array}{c}\text { Measurement } \\
\text { date }\end{array}$ & \multicolumn{2}{c}{$\begin{array}{c}\text { Without } \\
\text { biopreparation }\end{array}$} & \multicolumn{2}{c}{$\begin{array}{c}\text { With } \\
\text { biopreparation }\end{array}$} \\
\cline { 3 - 6 } & & 68 & 88 & 63 & 86 \\
& & Facility I & Facility II & Facility I & Facility II \\
\hline 0 & II & 33 & 58 & 26 & 60 \\
50 & & 14 & 29 & 11 & 55 \\
100 & & 90 & 94 & 82 & 88 \\
0 & III & 80 & 90 & 74 & 80 \\
50 & & 55 & 51 & 55 & 80 \\
\hline 100 & & & & &
\end{tabular}

Figure 1 shows the course of compaction measured in facility I on particular measurement dates without the use of biopreparation. Very high values of compactness were re- 
ported. On the first measurement date for $100 \%$ of the usage level, the compactness reached the highest value equal to 4.8 MPa to the penetration depth $0.15 \mathrm{~m}$. Soil in particular measurement dates had varied moisture. Low moisture of soil on the first date resulted in fast increase of compactness to the penetration depth of $0.015 \mathrm{~m}$. It was related to direct impact of the roller. When this depth was exceeded, dynamics of increase decreased clearly and comparable values of compactness for 0 and $100 \%$ usage level for the penetration depth of $0.15 \mathrm{~m}$ prove limited impact of the roller. Higher moisture level of soil on the 2nd and 3rd date enabled deeper impact of the roller thus differentiating to a higher extent compactness within the soil profile of particular usage levels.

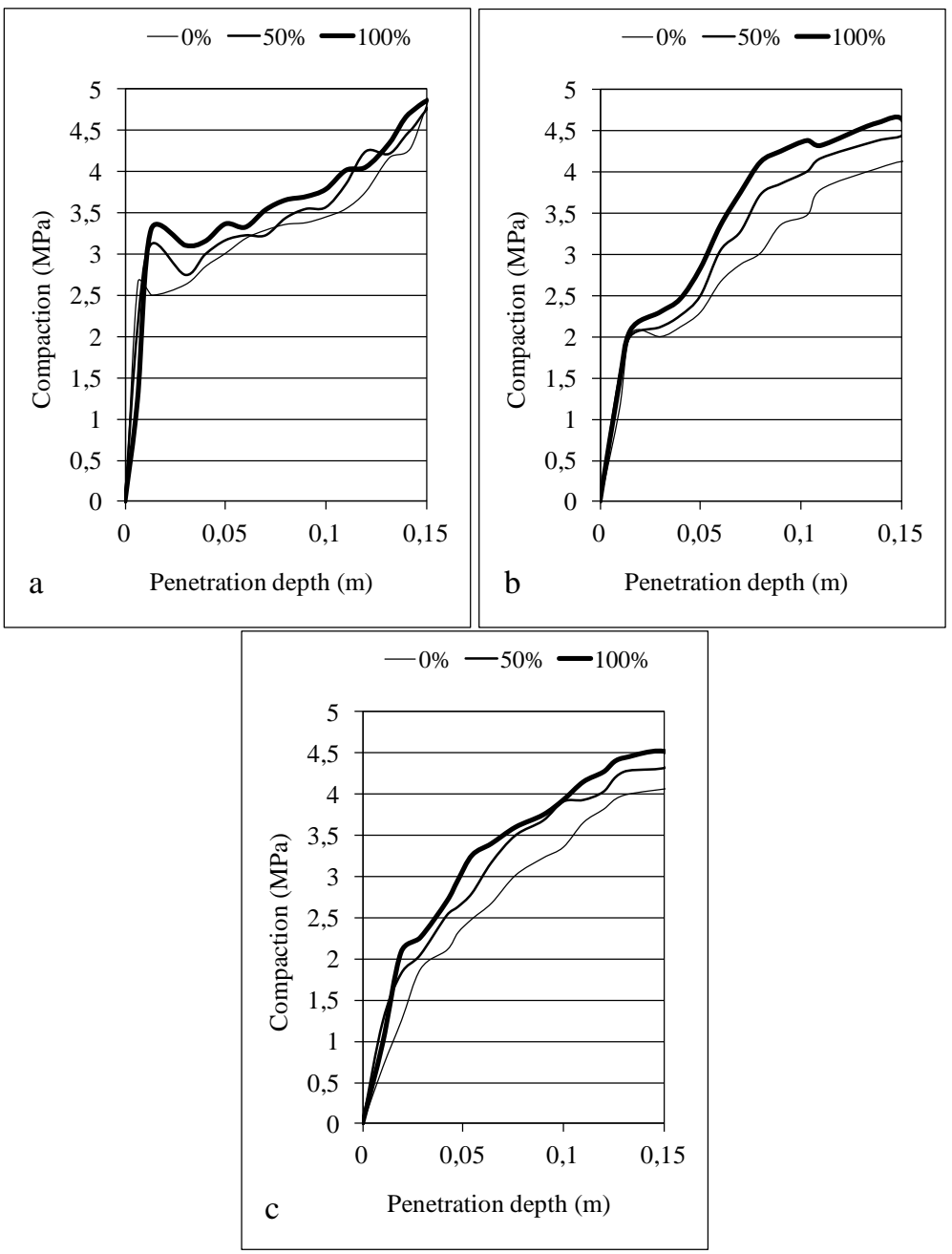

Figure 1. Compaction course. Facility I, $a-I$ date, $b-I I$ date, c - III date without biopreparation 
Assessment of changes...

Figure 2 shows the course of compaction measured in facility I on particular measurement dates with the use of biopreparation. It was reported that the nature of changes of the parameter values was similar to facilities where biopreparation was not applied. In comparison to the 1st measurement date, reduction of compactness on the 1st and 2nd measurement date at all usage levels was reported. It was related to the increase of sodding and higher soil moisture.
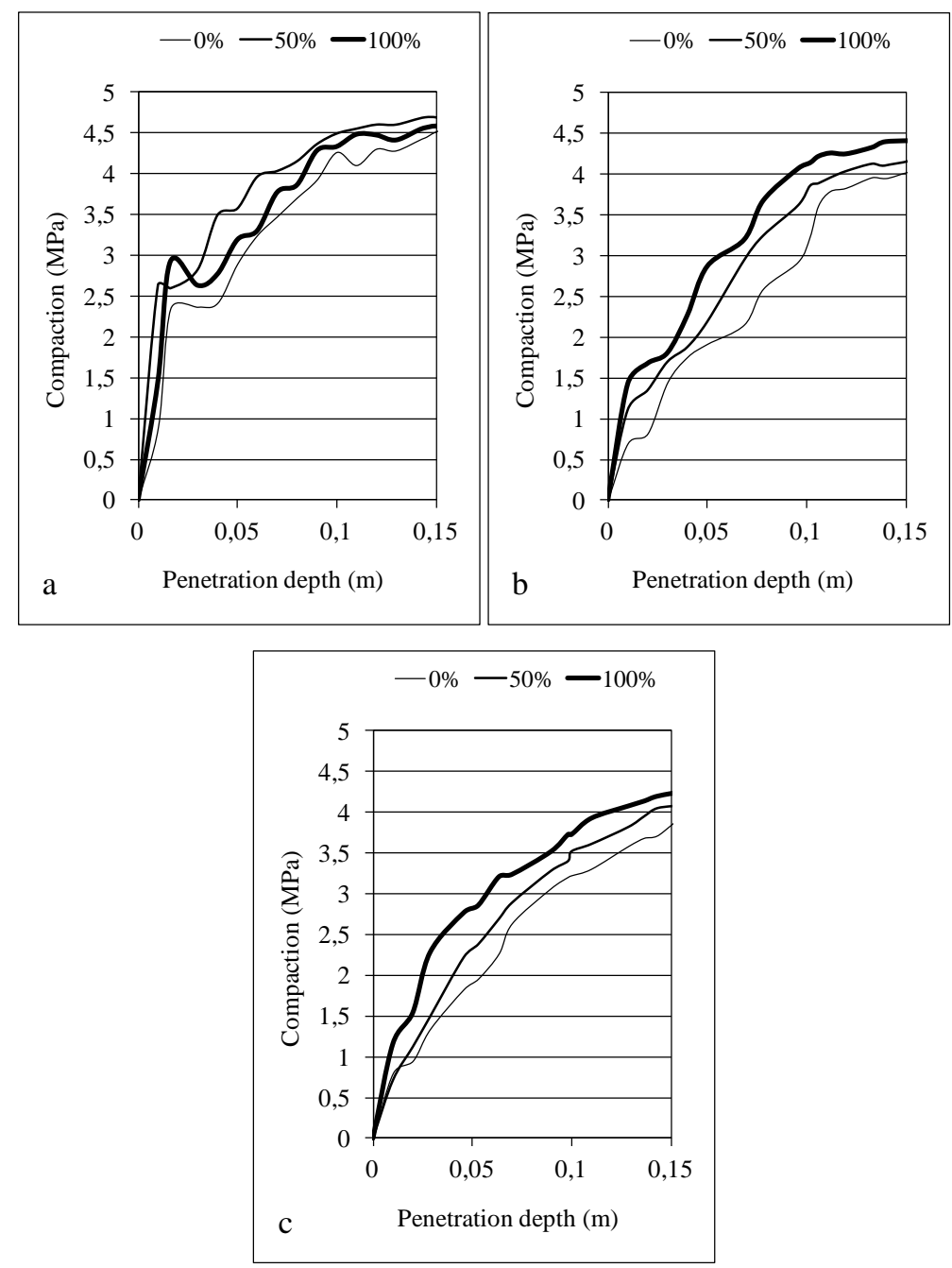

Figure 2. Compaction course. Facility I, a - I date, b-II date, c-III date with biopreparation 
Figure 3 shows the course of compaction measured in facility I on particular measurement dates without the use of biopreparation. Orchard grass which forms sod of this facility had greater strength to usage (higher sodding) in comparison to perennial rye-grass which grows in facility I. It enabled reduciton of soil compaction visible as early as on the 1st date, the maximum compaction for $100 \%$ level of usage and penetration depth of $0.15 \mathrm{~m}$ was 4.3 MPa. Higher moisture reported on further measurement dates resulted in further reduction of the value of this parameter and its explicit variability at particular usage levels.
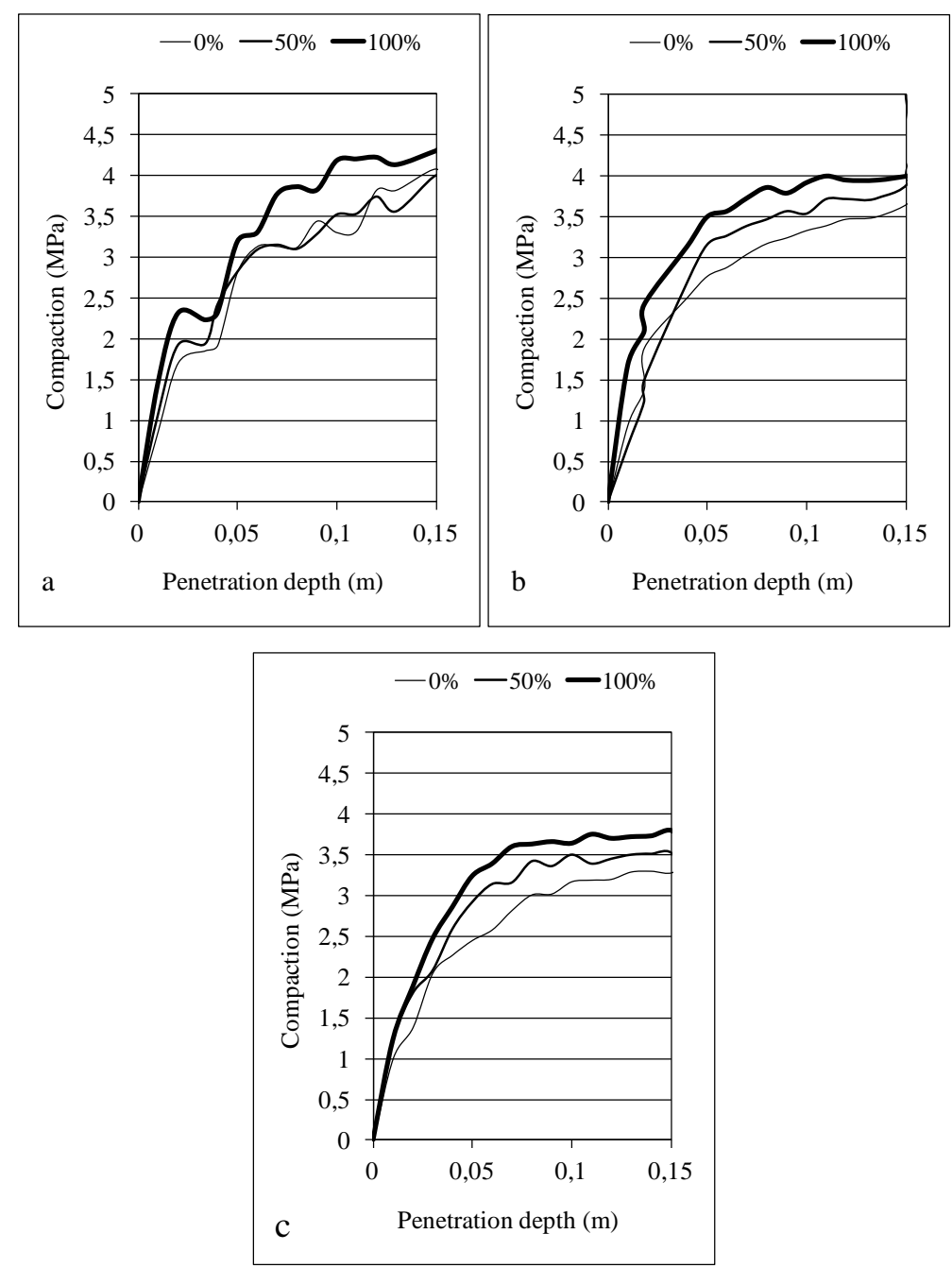

Figure 3. Compaction. Facility I, a - I date, b-II date, c-III date without biopreparation 
Assessment of changes...

Figure 4 shows the course of compaction measured in facility I on particular measurement dates with the use of biopreparation. Compaction courses on the I and II measurement dates were comparable to those measured in facilities without the use of biopreparation. On the 3rd measurement date in facility with $0 \%$ usage level, the maximum compaction values corresponding to those measured on the 2nd date were reported. Most probably, a situation occurred which was related to higher resistance of this sod to usage; reduction of sodding was lower than in facilities II without the use of biopreparation. On the other hand, in facilities with 50 and $100 \%$ usage level, a decrease of the value of this parameter was reported, which could have affected higher susceptibility of ground to deformation, particularly under the conditions of lower sodding and increased soil moisture (Horn et al., 1994).

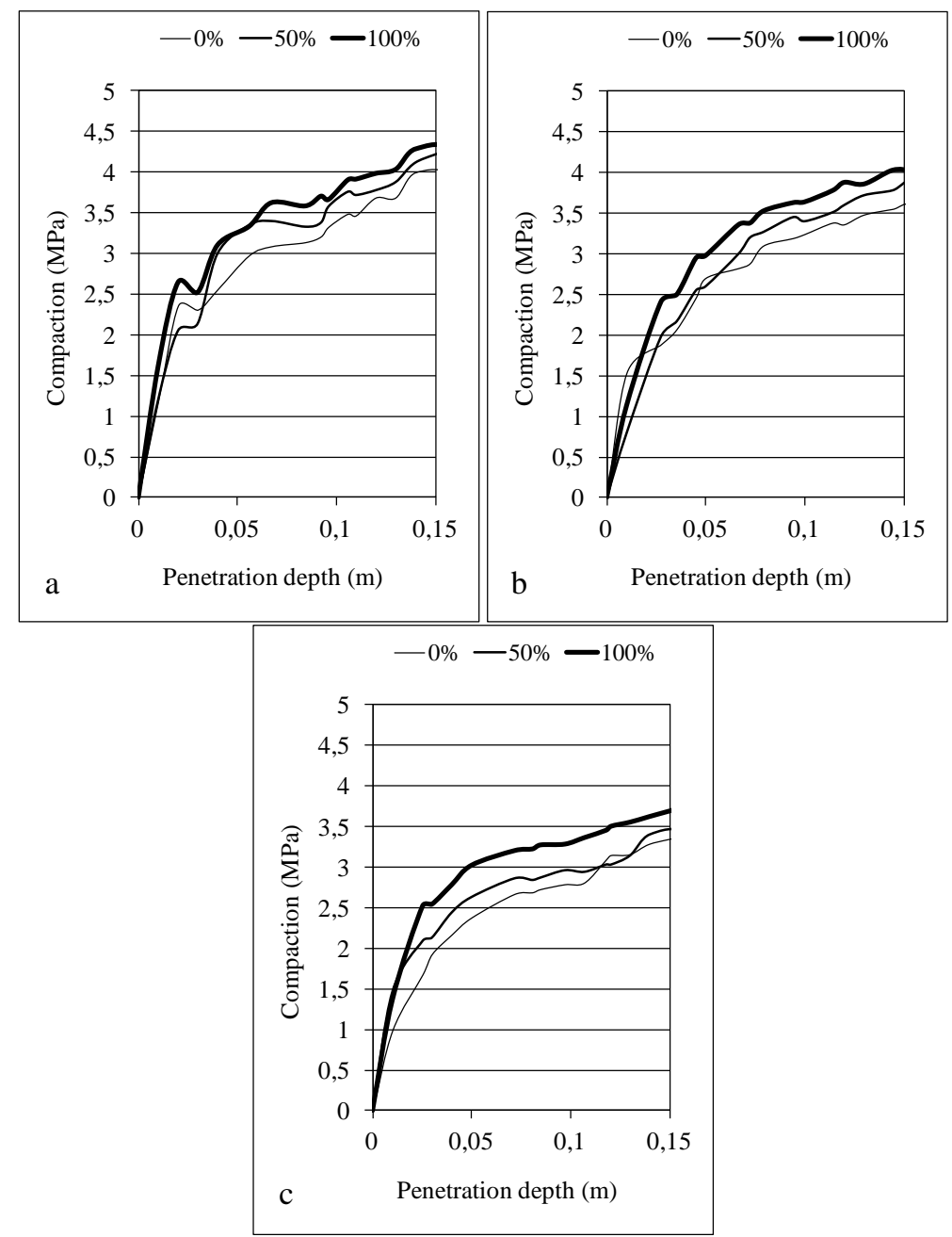

Figure 4. Compaction. Facility I, a - I date, b-II date, c-III date with biopreparation 
Figure 5 shows values of maximum shear stresses measured in facility I with the use of biopreparation and without it. The obtained results correlated with the compaction results. For low soil moisture (I date) the maximum shear stresses reached the highest values, the increase of soil moisture resulted in the decrease of the value of this parameter. The increase of usage on all measurement dates resulted in higher values of maximum shearing stresses. It was also characteristic that no significant differences in the values of the subject parameters were reported between facilities with and without application of biopreparation. Thus, it may be stated that lower sodding may not always be related to the reduction of sod strength in the horizontal plane.

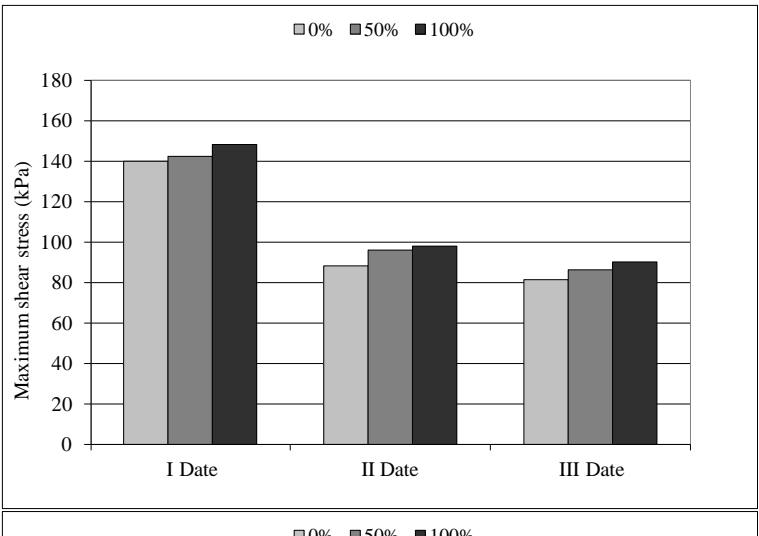

$\square 0 \% \quad \square 50 \% \square 100 \%$

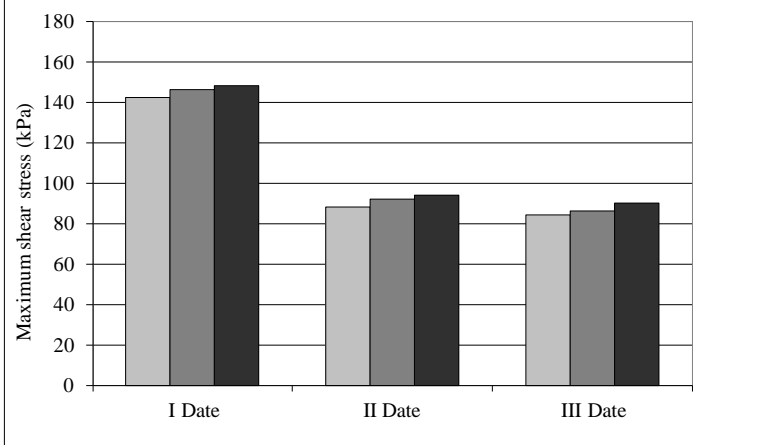

Figure 5. Maximum shear stress. Facility I, $a$ - without biopreparation, $b$ - with biopreparation

Figure 6 presents values of the maximum shear stresses measured in facility II with application of biopreparation and without it. A similar nature of changes of this parameter as in facilities was maintained, where for low soil moisture the highest values of maximum shear stresses were reported and the increase of soil moisture resulted in their reduction. In comparison to facility I higher values of this parameter were reported which was related to higher sodding. The highest values of $168 \mathrm{kPa}$ were measured on the 1st measurement date for $100 \%$ usage level in a facility without biopreparation. 
Assessment of changes...

Based on the obtained results, a multivariance analysis was carried out at the significance level of $\alpha=0.05$, with the use of Statistica 9.0. Results of analysis were presented in table 5. No impact of biopreparation on sodding changes and maximum shear stress were reported. However, the impact of the facility (species composition of sod), date of research and usage level on the values of analysed parameters were proved.
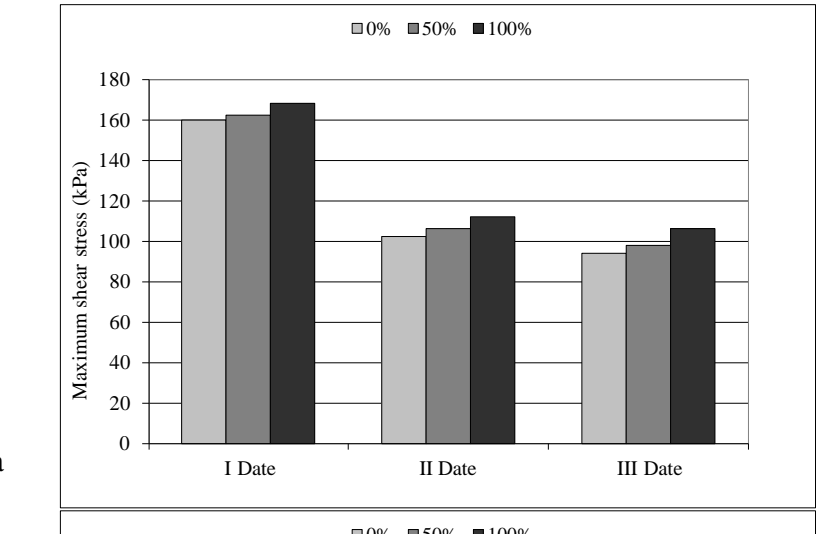

$\square 0 \% \quad \square 50 \% \quad \square 100 \%$

b

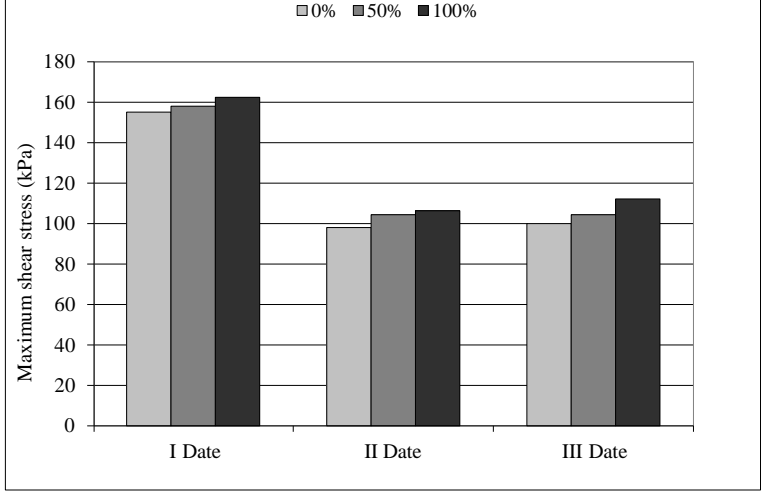

Figure 6. Maximum shear stress. Facility II, $a$ - without biopreparation, $b$ - with biopreparation

Table 5.

Results of statistical analysis

\begin{tabular}{lcccccc}
\hline \multirow{2}{*}{ Factor } & \multicolumn{2}{c}{ Compaction } & \multicolumn{2}{c}{ Sod formation } & \multicolumn{2}{c}{$\begin{array}{c}\text { Maximum } \\
\text { shear stress }\end{array}$} \\
\cline { 2 - 8 } & $\mathrm{F}$ & $\mathrm{p}$ & $\mathrm{F}$ & $\mathrm{p}$ & $\mathrm{F}$ & $\mathrm{p}$ \\
\hline Facility & 67.41 & $<0.000001$ & 52.39 & $<0.000001$ & 623.70 & $<0.000001$ \\
Application of & 18.85 & 0.000034 & 0.148 & 0.701745 & 0.4 & 0.535846 \\
biopreparation & 76.52 & $<0.000001$ & 132.34 & $<0.000001$ & 3948.4 & $<0.000001$ \\
Termin & 125.57 & $<0.000001$ & 88.13 & $<0.000001$ & 68.7 & $<0.000001$ \\
Usage level & & & & & &
\end{tabular}




\section{Conclusions}

1. The use of the investigated facilities resulted in the reduction of sod formation, which resulted from the sod formation species. The increase of soil compaction was determined under the conditions of intensive use. The increase of soil moisture in subsequent measurement dates caused the reduction of the soil compaction value and changes of its characteristics in the soil profile.

2. The value of maximum shearing stresses were growing along with intensity of use regardless the soil moisture.

\section{References}

Białczyk, W., Czarnecki, J., Cudzik, A., Brennensthul, M. (2010). Ocena właściwości trakcyjnych wybranych opon na podłożach zadarnionych. Inżynieria Rolnicza, 7(125), 15-22.

Błażejczak, D., Dawidowski, J. B., Śnieg, M., Tomaszewicz, T. (2008). Oddziaływanie gęstości i składu gleby na ocenę stanu jej zagęszczenia. Inżynieria Rolnicza, 4(102), 127-132.

Cook A., Mariott C., Seel W., Mullins C. (1996). Effects of soil mechanical ompedance on root and shoot growth of Lolium perenne L., Agrostis capillaris and Trifolium repens L. Journal of Experimental Botany. Vol. 47(301), 1075-1084.

Danneberger, T. (1993). Turfgrass ecology and Management. Franzak \& Foster, div. of G.I.E., Inc. Publishers. Cleveland, $\mathrm{OH}$.

Follis, C., Anderson, S., Fresenburg, B., Ervin, E. (2008). Evaluation of sand-soil-compost root zones developed for athletic fields. Acta Horticulturae, 783, 97-101.

Grime, J., Hodgson, J., Hunt, R. (1992). Comparative plant ecology. Chapman and Hall. London.

Głąb, T. (1999). Reakcja koniczyny łąkowej na ugniatanie kołami ciągnika. Inżynieria Rolnicza, 4(10), 37-43.

Horn, R., Lebert, M. (1994). Soil Compactability and Compressibility. Developments in Agricultural Engineering, Elsevier Vol. 11, 45-69.

Janik, G., Wolski, K., Daniel, A., Albert, M., Skierucha, W., Wilczek, A., Szyszkowski, P., Walczak, A. (2015). TDR Technique for Estimating the Intensity of Evapotranspiration of Turfgrasses. The Scientific World Journal. Article ID 626545, 11.

Kopeć, S., Głąb, T. (2002). Wpływ ugniatania gleby na plonowanie i system korzeniowy życicy trwałej. Łakarstwo w Polsce. 5, 123-128.

McNitt, A., Landschoot, P., Waddington, D. (2004). Effects of turfgrass, cutting height and soil conditions on traction. Acta Horticulturae. 661, 39-48.

McCarty, L., Gregg, M., Toler, J., Camberato, J., Hill, H. (2005). Minimizing thatch and mat development in a newly seeded creeping bentgrass golf green. Crop Science 45(4), 1529-1535.

Samaranayake, H., Lawson, T., Murphy, J. (2008). Traffic Stress Effects on Bentgrass Putting Green and Fairway Turf. Crop Science. 48, 1193-1202.

Serensits, T., McNitt, A., Petrunak, D. (2011). Improving surface stability on natural turfgrass athletic fields. Journal of Sports Engineering and Technology, 225, 285-92.

Turgeon, A. (2005). Turfgras management. 7th edition. Opearson Prentice Hall. Upper sadle River. New Jersey. 


\section{OCENA ZMIAN ZACHODZĄCYCH W DARNI POD WPLYWEM INTENSYWNEGO UŻYTKOWANIA}

Streszczenie. W pracy przedstawiono wyniki badań, których celem była ocena zmian stopnia zadarnienia oraz wybranych parametrów wytrzymałościowych darni użytkowanej z różną intensywnością, dodatkowo darń modyfikowano poprzez podanie biopreparatu. Pomiary wykonano na dwóch rodzajach darni, z których pierwsza darń utworzona była z życicy trwałej, druga z kupkówki pospolitej. Wykazano, że użytkowanie badanych obiektów skutkowało spadkiem ich zadarnienia, które było ściśle związane z gatunkiem tworzącym darń. Nie wykazano wpływu stosowania biopreparatu na stopień zadarnienia. Intensywne użytkowanie wpływało na zwiększenie wartości analizowanych parametrów wytrzymałościowych, przy niskiej wilgotności gleby $(5,0-5,5 \%)$ zauważono znaczne zagęszczenie w wierzchniej warstwie gleby.

Słowa kluczowe: darń, zwięzłość, maksymalne naprężenia ścinające, zadarnienie 